\title{
COMPREHENSIVE BIBLIOMETRIC STUDY OF JOURNAL OF ENVIRONMENTAL ENGINEERING AND LANDSCAPE MANAGEMENT FROM 2007 TO 2019
}

\author{
Zeshui XU1, Wei ZHOU²*, Edita BALTRÉNAITÉ ${ }^{3}$ \\ ${ }^{1}$ Business School, Sichuan University, 610064 Chengdu, PR China \\ ${ }^{2}$ School of Finance, Yunnan University of Finance and Economics, 650221 Kunming, PR China \\ ${ }^{3}$ Institute of Environmental Protection, Vilnius Gediminas Technical University, \\ Sauletekio al. 11, LT-10223 Vilnius, Lithuania
}

Received 11 June 2019; accepted 1 August 2019

\begin{abstract}
Since the world became industrialized, our environment has been changed, bringing different environmental issues. The world benefits from industrialization but suffers from diverse pollutions simultaneously. Therefore, we are motivated to investigate the environment and landscape management explorations by analyzing 403 papers published in the Journal of Environmental Engineering and Landscape Management (JEELM) from 2007 to 2019. As one of the scientific journals that investigate environment management, JEELM mainly focuses on the area of environmental changes caused by human activities. By analyzing the issues such as atmosphere, water, and soil pollution and their mitigation technologies, JEELM accepts the scientific outputs written in English. Based on the data retrieved from Web of Science, we provide an overview of the status quo and emerging trends of the researches published on JEELM. Diverse researches such as publication distribution, citation structure, co-citation analysis and key contributors on the aspects of countries, institutions, and authors are given to comprehensively analyze the current situation of JEELM's. Besides, the emerging trends and hot spots can be revealed by burst detection and timeline view. Therefore, this paper contributes to providing a general picture of the knowledge domain of JEELM' research which enables researchers, especially the beginners to learn about this journal's development.
\end{abstract}

Keywords: environmental engineering, landscape management, JEELM, bibliometrics, CiteSpace.

\section{Introduction}

Never in history was sustainability so significant for the development of the economy in different societies. With the increasing attention towards sustainability, environmental issues are gradually becoming one of the crucial elements for economic growth, leading more journals to discuss the effective methods for environmental management. Among these journals, Journal of Environmental Engineering and Landscape Management (JEELM) made some contributions to the research of environmental changes caused by human activities and the sustainability-related investigations. As a research journal, JEEML was produced by Vilnius Gediminas Technical University (VGTU). It was acknowledged by The Lithuanian Academy of Sciences and The International Academy of Ecological and Life Protection Sciences (IAELPS).
Besides, JEELM is also one of the associate members of the Public Information Department of the United Nations. Being published in 1995, Journal of Environmental Engineering was established instead of proceedings from the previous research Environmental Protection of Vilnius Technical University. Then 6 issues were published between 1995 and 1998. Since 1998, the Journal of Environment Engineering released its scientific articles in volumes. From 2003, this journal was renamed as Journal of Environmental Engineering and Landscape Management, receiving research articles in English and Lithuanian. With the aim of publishing the original investigations that focus on the environment, JEELM mainly pays attention to the changes brought by human activities and the research outputs related to sustainability. Specifically, there are many articles published by JEELM analyze the atmosphere and air pollution. Also, water and soil contaminations are in

${ }^{*}$ Corresponding author. E-mail: $z w 453 @ 163 . c o m$ 
the scope of the journal's investigation. How to control and mitigate these pollutions by utilizing effective technologies is the main stream in JEELM as well. The articles such as short reports, observations, and reviews, reports on conferences and workshops are also in the consideration of publishing. As a result, it can be found that JEELM is an interdisciplinary and international journal, which covers diverse forms of research outputs.

In order to know the development, the current status and the emerging trends of the research articles published on JEELM, this paper provides a scientometric analysis to comprehensively investigate the knowledge domain of research published on this journal. According to Chen, $\mathrm{Hu}$, Liu, and Tseng (2012), scientometrics belongs to the field of informatics which quantitatively investigates scientific articles to learn emerging trends and the knowledge structure of a certain research area. Therefore, in this paper, an effective bibliometric tool namely CiteSpace is selected as the main methods to analyze the publications of JEELM. As introduced by Chen (Chen, 2006, 2017; Chen et al., 2012), CiteSpace presents a synthesized network to demonstrate the intellectual structure of a knowledge domain on the basis of a time series of networks derived from annual publications. Different bibliometric studies are involved in CiteSpace such as co-citation analysis in terms of documents and authors, collaboration network and geospatial visualizations. Besides, there are also other bibliometric tools which are broadly utilized in various research areas such as VOSviewer (Van-Eck \& Waltman, 2009; Stopar \& Bartol, 2019), Bicomb (Lu, Li, \& Arthur, 2014; Zhao et al., 2018; Yu, Xu, \& Šaparauskas, 2019), and BibExcel (Qaiser, Ahmed, Sykora, Choudhary, \& Simpson, 2017; Tian et al., 2018). The timeline and the burst detection analyses provided by CiteSpace could comprehensively illustrate the landmark articles and keywords in certain time periods. Therefore, hot spots and emerging trends of a research area can be revealed.

Since its establishment, CiteSpace has been widely applied in different fields. For instance, Morar and Agachi (2010) reviewed the development of heat integration and heat exchanger network synthesis (HENS) by utilizing CiteSpace. By investigating the relations between disciplines, authors and journals with the research area, the visualized network, and structure of HENS are presented in an easy understanding way. Niazi and Hussain (2011) focused on agent-based computing and analyzed the complex network in terms of the domain, detailed visualization-based of the bibliographic data by applying CiteSpace. In recent years, there has been an increasing number of researches using CiteSpace to comprehensively investigate diverse areas such as the computer and information ethics (Heersmink, Hoven, Eck, \& Berg, 2011), the GIS research (Wei, Grubesic, \& Bishop, 2015), the information literacy assessment (Pinto, 2015), and the aggregation operator research (Yu, 2015). Recently, based on the new and improved version, CiteSpace 5.0-5.4, which can be used to show the more visualizations and results, Cui and Zhang
(2018), Zhang and Li (2018), Ekanayake et al. (2019), and Zhong et al. (2019) respectively reviewed the research on circular economy, urban resilience and sustainability, value management, and the ontology research. Therefore, it can be seen that CiteSpace is an effective method to assist scholars in various field with their bibliometric studies.

Obviously, there are also some researches that analyze the bibliometric development of specific journals. Pinto, Barquin, Gonzalez, and Kauric (2009) presented an analysis of the social network by retrieving the data on the Journal of Documentation. Valenzuela, Merigo, Johnston, Nicolas, and Jaramillo (2017) revealed the contribution made by the Journal of Business \& Industrial Marketing based on bibliometric methodologies. Recently, Francisco, Mercedes, and Bartolomé (2016), Yu, Xu, Pedrycz, and Wang (2017), Tang, Liao, and $\mathrm{Su}$ (2018), Xu, Yu, and Wang (2019), and Thijs and Glanzel (2018) overviewed the development trends of International Journal of Hospitality Management, Information Sciences, International Journal of Fuzzy Systems, International Journal of Machine Learning and Cybernetics, and Scientometrics from the perspective of bibliometrics, respectively. Besides, journals are classified based on their scope of research. The scientometric investigations about journals in certain areas are also how scholars explore the development trends in different disciplines. A ranking of 69 marketing journals based on a new Hirsch-type index was given by Touzani and Moussa (2010) to find out the relationship between the hg-ranking and rankings in previous citation-based investigations of market journals. In addition, Sebo et al. (2019) made an evaluation of the publication speed of manuscripts submitted to general medical journals. They revealed the relations between the publication speed and authors, papers and journal characteristics. These papers have received wide attention, and more comprehensive and insightful bibliometric analyses are presented to assist researchers with their investigations in diverse areas.

In order to present the comprehensive and insightful investigation about the papers published on JEELM, this paper introduces the focuses and editor list in Section 1. The publication and citation numbers and citation structure are analyzed in Section 2. The influential contributors in terms of papers, countries/regions and institutions, and the burst detections are given in Section 3 and Section 4, respectively. Section 5 focuses on the keyword network and timeline view analysis. Lastly, this paper ends up with some conclusions, which can be seen in the last section.

\section{Scope and focuses of JEELM}

In order to briefly learn the specific research streams of the publications in JEELM, the scope and focus of JEELM's investigation are listed in Table 1. It can be seen that the direction atmosphere and air pollution control and the pollution mitigation technologies rank at the first place, which is followed by the research of the pollution control and the pollution mitigation technologies in terms of 
water and soil. It can be seen that the pollutions in terms of atmosphere, water and soil and the approaches that mitigate these contaminations are considered as the most significant. Also, nuclear hydro physics and radioactive pollution are included in the scope of JEELM's research. Specifically, water management, landscape protection, and the modeling environmental process are the methods proposed by researchers, aiming at improving the environment from different perspectives. Other considerations such as environmental ethics, law, and management are involved. Therefore, the JEELM is multidisciplinary.

Table 1. The scope of the JEELM publications

\begin{tabular}{|c|l|}
\hline Rank & \multicolumn{1}{|c|}{ Scope } \\
\hline 1 & $\begin{array}{l}\text { Atmosphere and air pollution control and pollution } \\
\text { mitigation technologies }\end{array}$ \\
\hline 2 & $\begin{array}{l}\text { Water pollution control and pollution mitigation } \\
\text { technologies }\end{array}$ \\
\hline 3 & $\begin{array}{l}\text { Soil pollution control and pollution mitigation } \\
\text { technologies }\end{array}$ \\
\hline 4 & Entrails of the earth and their protection \\
\hline 5 & $\begin{array}{l}\text { Waste management including zero-waste } \\
\text { technologies }\end{array}$ \\
\hline 6 & Environmental expertise \\
\hline 7 & $\begin{array}{l}\text { Control over physical and technological } \\
\text { environmental impacts and reduction technologies }\end{array}$ \\
\hline 8 & Nuclear hydro physics and radioactive pollution \\
\hline 9 & Modeling environmental processes \\
\hline 10 & Environmental monitoring \\
\hline 11 & Landscape protection \\
\hline 12 & Environmental ethics \\
\hline 13 & Environmental law and management \\
\hline 14 & Quality of indoor and outdoor environments \\
\hline & \\
\hline
\end{tabular}

\section{Publication and citation numbers and citation structure}

\subsection{Data collection and analysis}

In this study, Web of Science (WOS) is chosen to be the data source as it is a platform that provides a huge number of detailed information about the articles published around the world, including the data from Science Citation Index Expanded (SCI-EXPANDED), Social Sciences Citation Index (SSCI), Arts \& Humanities Citation Index (A\&HCI) (Van-Leeuwen, 2006). Then, through searching the journal's name "Journal of Environmental Engineering and Landscape Management", we found 403 papers are published from 2007 to May 2019.

We select the bibliometric tool namely CiteSpace to analyze the data retrieved from WoS and present the knowledge domain of JEELM. CiteSpace is one of the most popular bibliometric methods to simplify and clarify co-citation networks of all the papers; hence they could reflect the structure and characteristics of the research field (Chen, 2006).

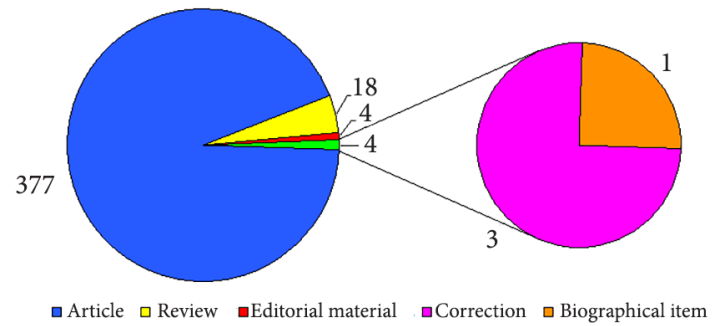

Figure 1. Types of the JEELM publications

On the basis of the analytic results given by WoS, we can get Figure 1 and find that the research outputs published on JEELM are classified into 5 types. Remarkably, the number of articles is far more than other types of publications. Specifically, 18 papers are considered as reviews, 4 papers are about editorial material, 3 papers are identified as the correction. Furthermore, there is only one biographical item. These also show that JEELM focuses on the academic article.

\subsection{Annual publication distribution and citation structure of JEELM}

There are 403 papers released on JEELM between 2007 and 2019 according to the searching results on WoS. Figures 2 and 3 present the information of the publication number and citation number of JEELM, respectively between 2007 and 2019. It can be seen from Figure 2 that there is a large number of papers published in 2007. However, it decreases sharply in 2008. After that, the publication amount of JEELM climbs between 2008 and 2010 year by year. Notably, it reaches a peak in 2010. Although the publication number experiences some fluctuations after 2010, it is still in a slightly declining trend. Figure 3 lists the citations received by JEELM between 2007 and 2019. It is noteworthy that the number of citations rises rapidly from 2007 to 2011. Compared with 2010, the number of citations in 2011 grows sharply. Therefore, it can be found that the papers published between 2007 and 2011 made great help to the study for the publications of JEELM in 2011. Based on Table 2, more influential papers were published between 2007 and 2011; therefore, the achievement in this period has a significant influence on the later research in the field. The number of citations falls in 2012.

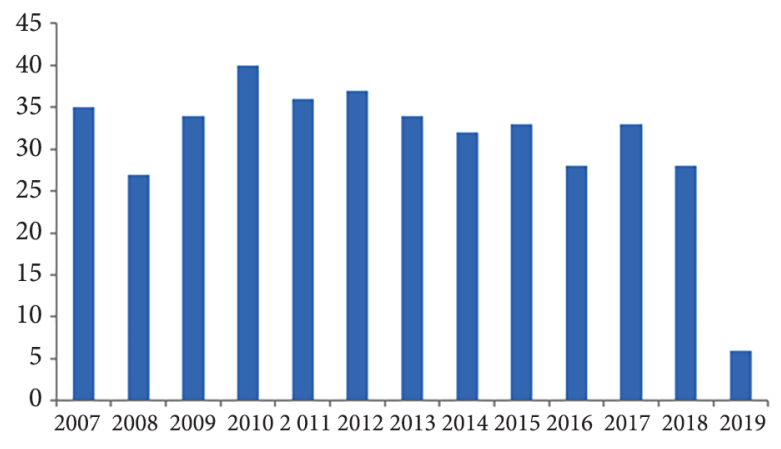

Figure 2. Distributions of the JEELM publications by year (2007-2019) 


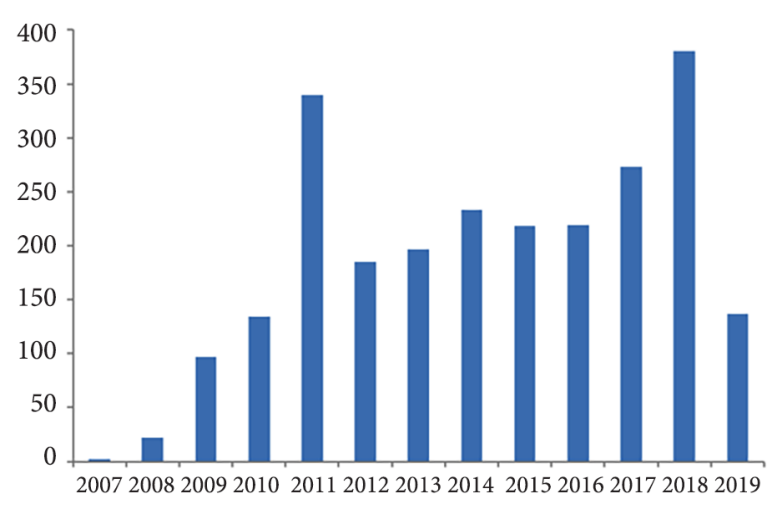

Figure 3. Annual distributions JEELM's citation number (2007-2019)

Additionally, the number of citations rise rapidly again between 2016 and 2018, indicating that previous papers published in JEELM also impact on the development and study of the current research area. In addition, Table 2 is provided to explore more detailed information about JEELM publications. "TP" is the total publications, "TC" denotes the total citations until May of 2019 in each year, "AC" represents the average citations per paper, " $\geq 50$ ", " $\geq 20$ ", " $\geq 10$ ", " $\geq 5$ " and " $\geq 1$ " are different intervals which reflect the number of citations. As well as, $\mathrm{H}$-index could accurately and successfully reflect academic achievements. Moreover, a higher $\mathrm{H}$-index implies a greater achievement (Hirsch, 2005). We can see that the papers published between 2007 and 2010 have the most TC, AC, and maximum $\mathrm{H}$-index. Hence, it is obvious that the JEELM publications in these years significantly impact on this journal. Based on the data collection from WoS, only two papers conform the standard of " $\geq 50$ ", in other words, this paper has been cited above 50 times. Moreover, these two articles are introduced and analyzed in the following section, namely the first and second papers in Table 3.

\section{Influential contributors in terms of papers, countries/regions, and institutions}

Table 3 lists the top 30 most cited papers in JEELM from 2007 to May 2019. Obviously, the paper "Sustainable construction taking into account the building impact on the environment" (Medineckiene, Turskis, \& Zavadskas, 2010) was frequently cited 67 times. This paper depicted the impact of construction on the environment and the people's health. Based on it, the authors provide an optimal approach of building construction, which could meet the environmental control standards. The paper "Phytoremediation for heavy metal-contaminated soils combined with bioenergy production" (Ginneken et al., 2007) was cited more than 60 times. As a result, it is a vital reference to the later papers. It describes the application of phytoremediation to clean soil polluted by heavy metals. By adding biodegradable physicochemical agents to plant, more heavy metals can be cleaned.

Additionally, the authors also researched and compared different energy-recovery-techniques that could make harvested biomass crops convert into bioenergy. The third-ranked journal is "An approach to the multi-attribute assessment of indoor environment before and after the refurbishment of dwellings" (Zavadskas, Kaklauskas, Turskis, \& Kalibatas, 2009). It analyzed the relationship between indoor environmental status and residents' need and the Lithuanian Hygienic Norm, the researchers offered access for multi-attribute assessment of residences before and after refurbishment and/ or renovation.

In these 30 papers, we can find that there is no paper published in recent years, thus the papers published in recent years still need time to catch up. Generally, the top 30 most cited papers all promoted the development of the journal and the related fields.

Table 2. JEELM publication characteristics between 2007 and 2019

\begin{tabular}{|c|c|c|c|c|c|c|c|c|c|}
\hline Year & TP & TC & AC & H-index & $\geq 50$ & $\geq 20$ & $\geq 10$ & $\geq 5$ \\
\hline 2007 & 35 & 372 & 10.63 & 11 & 1 & 5 & 14 & 22 & 34 \\
\hline 2008 & 27 & 286 & 10.59 & 11 & 0 & 4 & 12 & 21 & 25 \\
\hline 2009 & 34 & 356 & 10.47 & 12 & 0 & 5 & 17 & 22 & 33 \\
\hline 2010 & 40 & 423 & 10.58 & 12 & 1 & 7 & 14 & 25 & 35 \\
\hline 2011 & 36 & 165 & 4.58 & 7 & 0 & 1 & 5 & 16 & 31 \\
\hline 2012 & 37 & 212 & 5.73 & 8 & 0 & 2 & 7 & 15 & 33 \\
\hline 2013 & 34 & 140 & 4.12 & 6 & 0 & 1 & 4 & 10 & 31 \\
\hline 2014 & 32 & 127 & 3.97 & 7 & 0 & 0 & 2 & 12 & 26 \\
\hline 2015 & 33 & 105 & 3.18 & 6 & 0 & 0 & 1 & 8 & 27 \\
\hline 2016 & 28 & 92 & 3.29 & 5 & 0 & 0 & 2 & 6 & 23 \\
\hline 2017 & 33 & 155 & 4.70 & 7 & 0 & 1 & 6 & 8 & 26 \\
\hline 2018 & 28 & 4 & 0.14 & 1 & 0 & 0 & 0 & 0 & 4 \\
\hline 2019 & 6 & 0 & 0 & 0 & 0 & 0 & 0 & 0 & 0 \\
\hline Total & 403 & 2437 & - & - & 2 & 26 & 84 & 165 & 328 \\
\hline Percentage & - & - & - & - & $0.49 \%$ & $6.45 \%$ & $20.84 \%$ & $40.94 \%$ & $81.39 \%$ \\
\hline
\end{tabular}


Table 3. Top 30 most cited papers in JEELM between 2007 and 2019

\begin{tabular}{|c|c|c|c|c|c|}
\hline Rank & Title & Author(s) & $\mathrm{TC}$ & Year & $\mathrm{AC}$ \\
\hline 1 & $\begin{array}{l}\text { Sustainable construction taking into account the building impact } \\
\text { on the environment }\end{array}$ & Medineckienè et al. & 67 & 2010 & 6.7 \\
\hline 2 & $\begin{array}{l}\text { Phytoremediation for heavy metal-contaminated soils combined } \\
\text { with bioenergy production }\end{array}$ & Ginneken et al. & 66 & 2007 & 5.08 \\
\hline 3 & $\begin{array}{l}\text { An approach to multi-attribute assessment of indoor environment } \\
\text { before and after refurbishment of dwellings }\end{array}$ & Zavadskas et al. & 41 & 2009 & 3.73 \\
\hline 4 & $\begin{array}{l}\text { Intuitionistic fuzzy EDAS method: An application to solid waste } \\
\text { disposal site selection }\end{array}$ & Kahraman et al. & 34 & 2017 & 11.33 \\
\hline 5 & Spatial distribution of heavy metals released from ashes after a wildfire & Pereira and Úbeda & 34 & 2010 & 3.4 \\
\hline 6 & $\begin{array}{l}\text { Application of numerical models to evaluate oil spills propagation } \\
\text { in the coastal environment of the black sea }\end{array}$ & Rusu & 32 & 2010 & 3.2 \\
\hline 7 & $\begin{array}{l}\text { Fuzzy multiple criteria assessment of construction site alternatives } \\
\text { for non-hazardous waste incineration plant in Vilnius city, applying } \\
\text { ARAS-F and AHP methods }\end{array}$ & Turskis et al. & 31 & 2012 & 3.88 \\
\hline 8 & $\begin{array}{l}\text { Removal of nitrates and ammonium ions from water using natural } \\
\text { sorbent zeolite (clinoptilolite) }\end{array}$ & Mažeikienè et al. & 31 & 2008 & 2.58 \\
\hline 9 & $\begin{array}{l}\text { Environmental evaluation of waste management scenarios-significance } \\
\text { of the boundaries }\end{array}$ & Ghinea et al. & 30 & 2012 & 3.75 \\
\hline 10 & $\begin{array}{l}\text { Investigation into the air treatment efficiency of biofilters of different } \\
\text { structures }\end{array}$ & $\begin{array}{l}\text { Baltrènas and } \\
\text { Zagorskis }\end{array}$ & 30 & 2010 & 3 \\
\hline 11 & $\begin{array}{l}\text { Search for optimal solution of public building renovation in terms } \\
\text { of life cycle }\end{array}$ & $\begin{array}{l}\text { Užšilaitytè and } \\
\text { Martinaitis }\end{array}$ & 29 & 2010 & 2.9 \\
\hline 12 & $\begin{array}{l}\text { Assessment of primary factors causing positive or negative local } \\
\text { perceptions on protected areas }\end{array}$ & Alkan et al. & 26 & 2009 & 2.36 \\
\hline 13 & Ultraviolet radiation albedo of natural surfaces & $\begin{array}{l}\text { Chadyšiene and } \\
\text { Girgždys }\end{array}$ & 26 & 2008 & 2.17 \\
\hline 14 & $\begin{array}{l}\text { Investigation into emissions of gaseous pollutants during sewage } \\
\text { sludge composting with wood waste }\end{array}$ & $\begin{array}{l}\text { Zigmontienè and } \\
\text { Zuokaité }\end{array}$ & 25 & 2010 & 2.5 \\
\hline 15 & $\begin{array}{l}\text { Comparing environmental impacts of natural inert and recycled } \\
\text { construction and demolition waste processing using LCA }\end{array}$ & Simion et al. & 23 & 2013 & 3.29 \\
\hline 16 & Modelling of motor transport exhaust gas influence on the atmosphere & Baltrènas et al. & 23 & 2008 & 1.92 \\
\hline 17 & $\begin{array}{l}\text { Mathematical simulation of solid particle dispersion in the air } \\
\text { of Vilnius city }\end{array}$ & Baltrènas et al. & 23 & 2008 & 1.92 \\
\hline 18 & $\begin{array}{l}\text { Anthropogenic effects on heavy metals and macronutrients } \\
\text { accumulation in soil and wood of Pinus sylvestris L }\end{array}$ & Pundytè et al. & 22 & 2011 & 2.44 \\
\hline 19 & $\begin{array}{l}\text { Investigation of volatile organic compound (VOC) emission in oil } \\
\text { terminal storage tank parks }\end{array}$ & Paulauskienè et al. & 22 & 2009 & 2 \\
\hline 20 & $\begin{array}{l}\text { Investigation of cleaning efficiency of a biofilter with an aeration } \\
\text { chamber }\end{array}$ & $\begin{array}{l}\text { Baltrènas and } \\
\text { Zagorskis }\end{array}$ & 22 & 2009 & 2 \\
\hline 21 & $\begin{array}{l}\text { Analysis of numerical modelling of turbulence in a conical reverse-flow } \\
\text { cyclone }\end{array}$ & $\begin{array}{l}\text { Vaitiekūnas and } \\
\text { Jakštonienè }\end{array}$ & 21 & 2010 & 2.1 \\
\hline 22 & Investigation of seaport air dustiness and dust spread & Baltrènas et al. & 21 & 2007 & 1.62 \\
\hline 23 & Effect of sewage sludge fertilization in short-rotation willow plantations & Lazdina et al. & 21 & 2007 & 1.62 \\
\hline 24 & $\begin{array}{l}\text { Hazard profile in manufacturing: determination of risk levels towards } \\
\text { enhancing the workplace safety }\end{array}$ & Reinhold and Tint & 20 & 2009 & 1.82 \\
\hline 25 & $\begin{array}{l}\text { Modelling of } \mathrm{Cu}, \mathrm{Ni}, \mathrm{Zn}, \mathrm{Mn} \text { and } \mathrm{Pb} \text { transport from soil to seedlings of } \\
\text { coniferous and leafy trees }\end{array}$ & $\begin{array}{l}\text { Baltrènaitè and } \\
\text { Butkus }\end{array}$ & 20 & 2007 & 1.54 \\
\hline 26 & $\begin{array}{l}\text { Application of agronomic practice improves phytoextraction on a } \\
\text { multipolluted site }\end{array}$ & Claus et al. & 20 & 2007 & 1.54 \\
\hline 27 & Lignin from steam-exploded wood as binder in wood composites & Grāvītis et al. & 19 & 2010 & 1.9 \\
\hline 28 & $\begin{array}{l}\text { Research on anaerobically treated organic waste suitability for soil } \\
\text { fertilisation }\end{array}$ & $\begin{array}{l}\text { Kvasauskas and } \\
\text { Baltrenas }\end{array}$ & 19 & 2009 & 1.73 \\
\hline 29 & Modeling of motor transport exhaust pollutant dispersion & $\begin{array}{l}\text { Vaitiekūnas and } \\
\text { Banaitytè }\end{array}$ & 19 & 2007 & 1.46 \\
\hline 30 & Efficiency evaluation of a noise barrier & Baltrènas et al. & 19 & 2007 & 1.46 \\
\hline
\end{tabular}




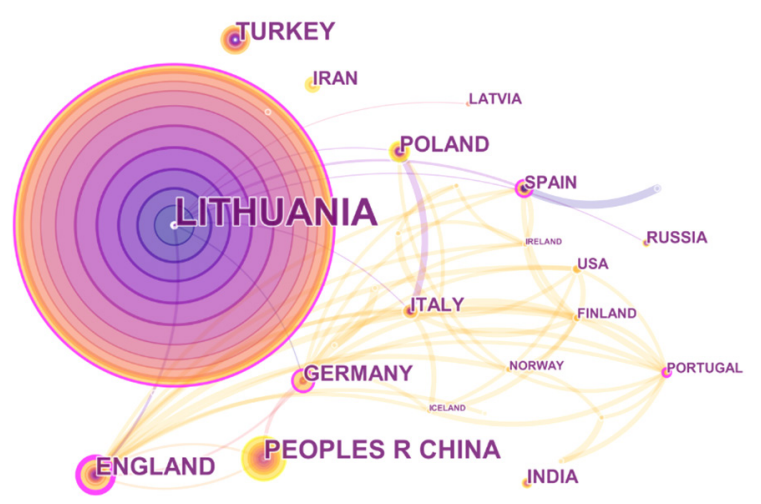

Figure 4. A visualization of the country collaboration network

Figure 4 illustrates the country collaboration network JEELM's publications. Combining with the analytic results in Table 4, the node size in Figure 4 represents the number of publications in each country. If the node size is bigger, the corresponding country has more publications. Furthermore, the density of the links of a country indicates the degree of geographic collaboration. If the lines connecting the corresponding node are denser, it means that the country has more collaboration with other countries. Similarly, the thinness of the links connecting the corresponding node implies a low level of international cooperation. From Figure 4, we can find that England,
Germany, Italy, and Portugal have more lines. Therefore, they have more collaboration with other countries. The top 10 most influential countries of the JEELM publications are listed in Table 4. Lithuania has the most TP, TC and highest $\mathrm{H}$-index.

In addition, it can be clearly seen that 10 papers of JEELM from Lithuania have more than 25 citations, 18 papers have more than 20 citations, and 26 papers have more than 15 citations, which are far more than other countries. Therefore, Lithuania is a big contributor to this journal. It should be noted that although Italy has only 12 publications on JEELM, it has the highest AC with 7.38 which means these papers significantly impact JEELM and the related research field. Among the above articles, we can find that the most cited paper entitled "Comparing environmental impacts of natural inert and recycled construction and demolition waste processing using LCA" (Simion, Fortuna, Bonoli, \& Gavrilescu, 2013) is aiming to quantify the environmental impacts of construction and demolition wastes recycling or reuse, and the authors concluded that the environmental impacts of construction and demolition wastes recycling or reuse account for about $40 \%$ of the impacts of natural inert processing. Notably, we find that all the 10 countries are from Europe or Asia.

Figure 5 shows a visualized collaboration network in terms of institutions. Similarly, we can see that Vilnius Gediminas Technical University, Martin Luther University, California State University-Stanislaus, Cranfield

Table 4. The top 10 most influential countries of the JEELM publications

\begin{tabular}{|c|l|l|c|c|c|c|c|c|c|c|c|c|}
\hline Rank & Country & Continent & TP & TC & AC & H-index & $\geq 25$ & $\geq 20$ & $\geq 15$ & $\geq 10$ & $\geq 5$ & $\geq 1$ \\
\hline 1 & Lithuania & Europe & 201 & 1468 & 7.3 & 19 & 10 & 18 & 26 & 53 & 98 & 183 \\
\hline 2 & China & Asia & 33 & 74 & 2.24 & 5 & 0 & 0 & 0 & 1 & 5 & 23 \\
\hline 3 & England & Europe & 25 & 149 & 5.96 & 8 & 0 & 0 & 1 & 6 & 12 & 23 \\
\hline 4 & Turkey & Asia & 25 & 160 & 6.4 & 7 & 2 & 2 & 2 & 4 & 13 & 23 \\
\hline 5 & Poland & Europe & 22 & 89 & 4.05 & 6 & 0 & 0 & 0 & 4 & 7 & 15 \\
\hline 6 & Germany & Europe & 18 & 141 & 7.83 & 8 & 0 & 1 & 3 & 7 & 10 & 16 \\
\hline 7 & Iran & Asia & 18 & 63 & 3.5 & 3 & 1 & 1 & 1 & 3 & 3 & 10 \\
\hline 8 & India & Asia & 14 & 79 & 5.64 & 5 & 0 & 0 & 2 & 3 & 6 & 11 \\
\hline 9 & Italy & Europe & 13 & 96 & 7.38 & 7 & 0 & 1 & 2 & 3 & 7 & 12 \\
\hline 10 & Latvia & Europe & 12 & 66 & 5.5 & 4 & 0 & 1 & 2 & 2 & 3 & 8 \\
\hline
\end{tabular}

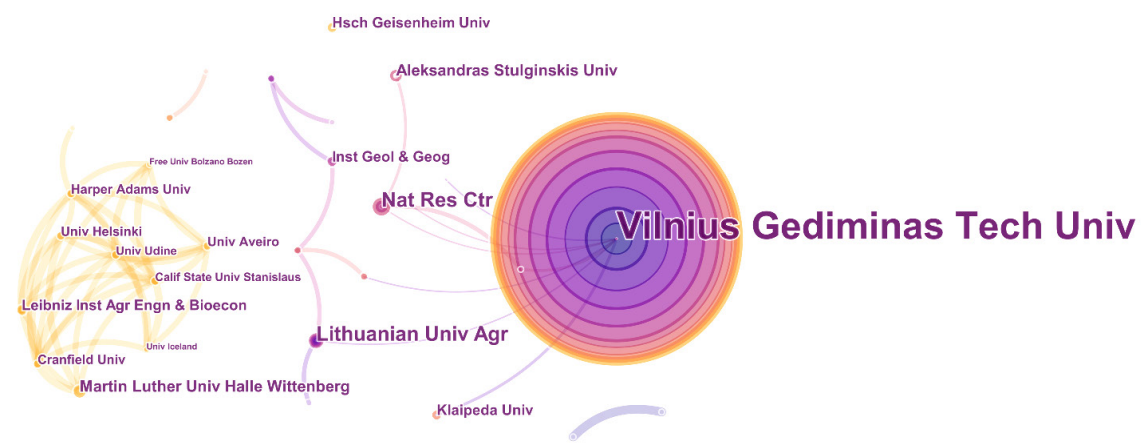

Figure 5. A visualization of the institution collaboration network 
University, University of Udine, University of Helsinki and Harper Adams University have more relations and collaboration with other institutions.

Furthermore, Table 5 is presented to demonstrate more details of the institutions that significantly impact JEELM. As the most prolific institutions, Vilnius Gediminas Technical University has the highest TP, TC and the highest $\mathrm{H}$ index which are obviously more than the second-ranked institution, Aleksandras Stulginskis University. Although TP of Nature Research Centre Lithuania is ranked in the third place, its AC is relatively less than others. Besides, Gheorghe Asachi Technical University of Iasi has higher AC than which of Aleksandras Stulginskis University. Therefore, the publications of the Gheorghe Asachi Technical University of Iasi have an important effect on the later research. Its most cited paper "Environmental evaluation of waste management scenarios - significance of

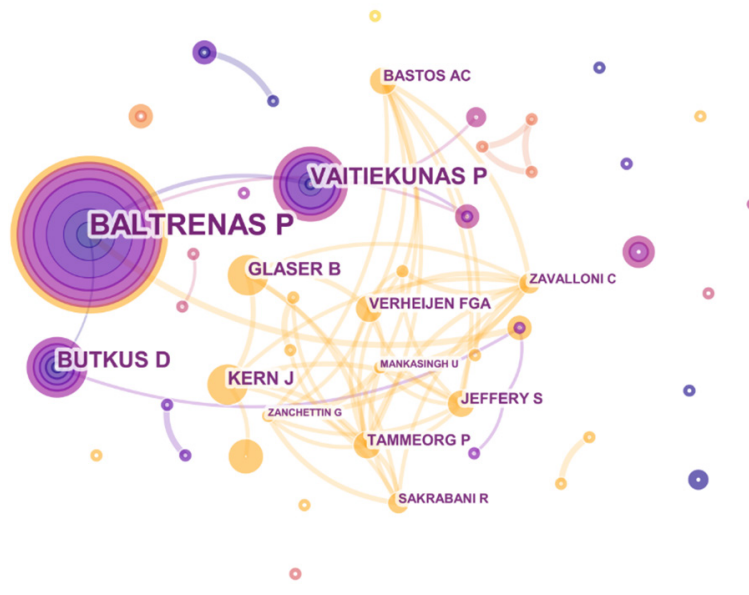

Figure 6. A visualization of the author collaboration network

Table 5. The top 13 most influential institutions of the JEELM publications

\begin{tabular}{|c|c|c|c|c|c|c|c|c|c|c|c|}
\hline Rank & Institution & $\mathrm{TP}$ & TC & $\mathrm{AC}$ & H-index & $\geq 40$ & $\geq 20$ & $\geq 15$ & $\geq 10$ & $\geq 5$ & $\geq 1$ \\
\hline 1 & Vilnius Gediminas Technical University & 129 & 1187 & 9.2 & 19 & 2 & 18 & 25 & 46 & 70 & 122 \\
\hline 2 & Aleksandras Stulginskis University & 20 & 96 & 4.8 & 6 & 0 & 0 & 1 & 3 & 10 & 19 \\
\hline 3 & Nature Research Centre Lithuania & 18 & 53 & 2.94 & 5 & 0 & 0 & 0 & 2 & 5 & 13 \\
\hline 4 & Vilnius University & 15 & 54 & 3.6 & 5 & 0 & 0 & 0 & 1 & 5 & 13 \\
\hline 5 & Klaipèda University & 9 & 62 & 6.89 & 4 & 0 & 1 & 1 & 3 & 4 & 7 \\
\hline 6 & $\begin{array}{l}\text { Lithuanian Research Centre for Agriculture } \\
\text { and Forestry }\end{array}$ & 9 & 26 & 2.89 & 3 & 0 & 0 & 0 & 0 & 3 & 9 \\
\hline 7 & Vytautas Magnus University & 9 & 46 & 5.11 & 5 & 0 & 0 & 0 & 1 & 5 & 8 \\
\hline 8 & Institute of Geology and Geography & 7 & 26 & 3.71 & 3 & 0 & 0 & 0 & 1 & 2 & 6 \\
\hline 9 & University of Wolverhampton & 7 & 24 & 3.43 & 3 & 0 & 0 & 0 & 1 & 2 & 5 \\
\hline 10 & Gheorghe Asachi Technical University of Iasi & 6 & 75 & 12.5 & 5 & 0 & 2 & 2 & 2 & 5 & 5 \\
\hline 11 & Kaunas University of Technology & 6 & 34 & 5.67 & 4 & 0 & 0 & 1 & 1 & 2 & 6 \\
\hline 12 & Martin Luther University Halle-Wittenberg & 6 & 46 & 7.67 & 3 & 0 & 0 & 1 & 3 & 3 & 5 \\
\hline 13 & $\begin{array}{l}\text { Moscow State University of Mechanical } \\
\text { Engineering }\end{array}$ & 6 & 16 & 2.67 & 2 & 0 & 0 & 0 & 0 & 1 & 5 \\
\hline
\end{tabular}

Table 6. The top 12 most influential authors of the JEELM publications

\begin{tabular}{|c|c|c|c|c|l|c|}
\hline Rank & TP & TC & AC & H-index & \multicolumn{1}{|c|}{ Author } & Percentage \\
\hline 1 & 26 & 299 & 11.5 & 12 & Baltrènas, P. & $6.45 \%$ \\
\hline 2 & 15 & 179 & 11.93 & 9 & Vaitiekūnas, P. & $3.72 \%$ \\
\hline 3 & 12 & 98 & 8.17 & 7 & Butkus, D. & $2.98 \%$ \\
\hline 4 & 10 & 85 & 8.5 & 6 & Baltrènaite, E. & $2.48 \%$ \\
\hline 5 & 8 & 33 & 4.13 & 4 & Booth, C. A. & $1.99 \%$ \\
\hline 6 & 7 & 57 & 8.14 & 5 & Vasarevičius, S. & $1.74 \%$ \\
\hline 7 & 7 & 45 & 6.43 & 3 & Paliulis, D. & $1.74 \%$ \\
\hline 8 & 7 & 44 & 6.29 & 4 & Girgždys, A. & $1.74 \%$ \\
\hline 9 & 6 & 176 & 29.33 & 4 & Zavadskas, E. K. & $1.49 \%$ \\
\hline 10 & 6 & 49 & 8.17 & 3 & Kern, J. & $1.49 \%$ \\
\hline 11 & 6 & 46 & 7.67 & 3 & Glaser, B. & $1.49 \%$ \\
\hline 12 & 6 & 38 & 6.33 & 4 & Girgždiené, R. & $1.49 \%$ \\
\hline Total & 116 & 1149 & - & - & - & $28.78 \%$ \\
\hline
\end{tabular}


the boundaries" (Ghinea, Petraru, Bressers, \& Gavrilescu, 2012) focuses on stressing in the optimal waste management alternative, system boundaries which are important for the life cycle impact assessment process.

The main author collaboration network of JEELM research is shown in Figure 6. We notice that Zavallonic, Jeffery, Baston, Mankasingh, Zanchettin, Tammeorg and Verheijen connect closely with other authors. In order to make a further investigation of the authors who contribute more to JEELM, a visualization of the author co-citation network is shown in Figure 7. We can reveal that Baltrenas and Butkus are both cited most by other authors. Table 6 lists the top 12 most influential authors in JEELM. From Table 6, we know that Baltrenas, as the editor-in-chief, has the highest TP, TC, and the highest $\mathrm{H}$-index. Zavadskas has only published 6 papers. However, he has the most AC with 29.33 which are more than twice that of the secondranked author. Compared with Table 3, there are 5 articles written by Zavadskas who is the first author or co-author. Thus, his publications on JEELM are greatly influential to the later authors.

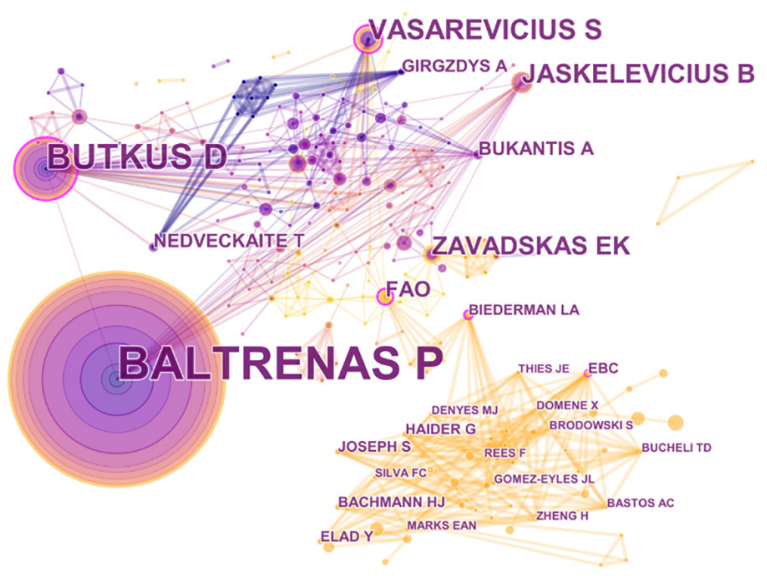

Figure 7. A visualization of the author co-citation network

\section{Burst detection analyses of the cited authors and the cited journals}

Citation burst detection reflects the explosive data that attracted attention by the academic in a certain period of time (Kleinberg, 2002). Table 7 lists the 11 frequently cited authors with the strongest citation bursts. We can derive the author who owns the longest citation burst duration is Baltrènas, the duration is 5 years from 2008 to 2012. Moreover, the citation burst of Jaskelevičius is the closest to the present.

The top 25 cited journals with the strongest citation bursts are presented in Table 8 . Here, the cited journals are the ones receive frequent citations by JEELM in a certain time period. The citation bursts of the cited journals of Journal of Environmental Radioactivity and Chemical Engineering Journal have the longest duration with 6 years. Journal of Environmental Radioactivity focuses on any aspect of the occurrence radioactivity in natural systems, and its impact factor is 2.263. Chemical Engineering Journal mainly pays attention to three parts of chemical engineering about chemical reaction engineering, environmental chemical engineering, and materials synthesis and processing. The journal aims to introduce discussions on new developments in chemical engineering, interpretative reviews, and original fundamental research. Among the cited journals with the strongest citation bursts, Atmospheric Environment, Aplinkos Inzinerija, Environmental Engineering and Journal of Environmental Radioactivity started in 2007, it is the earliest. The durations of cited journals with the strongest citation bursts of Chemical Engineering Journal, Environment Impact Assessment, Thesis, and Environmental Earth Sciences are up to now, which illustrate these journals still have an impact on JEELM and might even determine this journal's future research directions.

References with the strongest citation bursts are shown in Table 9. The reference of the earliest citation burst is "Investigation on the impact of transport exhaust emissions on the air" (Baltrènas, Vaitiekūnas, \& Mincevič, 2004).

Table 7. Top 11 cited authors with the strongest citation bursts

\begin{tabular}{|c|c|c|c|c|c|}
\hline Cited Authors & Year & Strength & Begin & End & 2007-2019 \\
\hline Baltrènas, $\mathrm{P}$. & 2007 & 14.3957 & 2008 & 2012 & 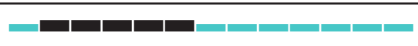 \\
\hline Butkus, D. & 2007 & 4.4122 & 2008 & 2012 & \\
\hline Oškinis, V. & 2007 & 2.8489 & 2008 & 2010 & 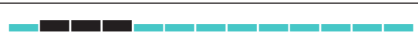 \\
\hline Jankauskaitė, M. & 2007 & 3.016 & 2009 & 2010 & 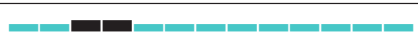 \\
\hline Jankaitë, A. & 2007 & 2.8171 & 2009 & 2011 & 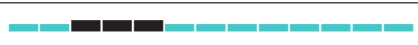 \\
\hline Laškova, T. & 2007 & 2.9438 & 2009 & 2011 & 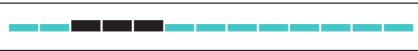 \\
\hline Baltrènaitè, E. & 2007 & 3.032 & 2010 & 2012 & 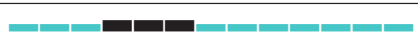 \\
\hline Kvasauskas, M. & 2007 & 2.9217 & 2010 & 2013 & \\
\hline Stravinskienė, V. & 2007 & 3.0484 & 2010 & 2011 & 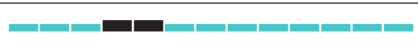 \\
\hline Jaskelevičius, B. & 2007 & 4.3012 & 2011 & 2015 & \\
\hline Alkan, H. & 2007 & 2.7704 & 2012 & 2013 & 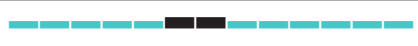 \\
\hline
\end{tabular}


This paper points out that the intensity of motor transport traffic could directly influent the concentrations of $\mathrm{CO}$ and aerosol particles. The reference "Investigation into the air treatment efficiency of biofilters of different structures"
(Baltrènas \& Zagorskis, 2010) has the longest citation burst duration with 4 years. Baltrenas and Zagorskis (2010) studied the dependences of the treatment efficiency of biofilters with different structures, concentration, and the

Table 8 . Top 25 cited journals with the strongest citation bursts

\begin{tabular}{|c|c|c|c|c|c|}
\hline Cited Journals & Year & Strength & Begin & End & $2007-2019$ \\
\hline Atmospheric Environment & 2007 & 5.6882 & 2007 & 2009 & 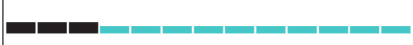 \\
\hline Aplinkos Inzinerija & 2007 & 10.0576 & 2007 & 2010 & مسمس \\
\hline Environmental Engineering & 2007 & 5.5297 & 2007 & 2011 & 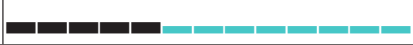 \\
\hline Journal of Environmental Radioactivity & 2007 & 3.7635 & 2007 & 2012 & 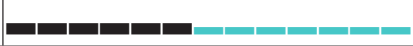 \\
\hline Applied Geochemistry & 2007 & 2.7869 & 2008 & 2011 & |- \\
\hline Journal of Bioscience and Bioengineering & 2007 & 3.2058 & 2008 & 2010 & - \\
\hline Energetika & 2007 & 3.4439 & 2008 & 2012 & - \\
\hline $\begin{array}{l}\text { Journal of Environmental Engineering and Landscape } \\
\text { Management }\end{array}$ & 2007 & 18.1356 & 2008 & 2012 & \\
\hline Ekologiya & 2007 & 6.6876 & 2008 & 2012 & - \\
\hline Aplinkos Tyrimai Inžinerija Ir Vadyba & 2007 & 3.4439 & 2008 & 2012 & |- \\
\hline Ecology & 2007 & 3.2766 & 2008 & 2011 & 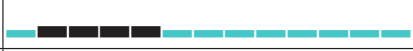 \\
\hline Geografijos Metraštis & 2007 & 3.2058 & 2008 & 2010 & -1 \\
\hline Forest Ecology and Management & 2007 & 3.7007 & 2009 & 2011 & 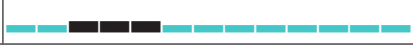 \\
\hline 7th International Conference Environmental Engineering & 2007 & 2.7087 & 2010 & 2011 & 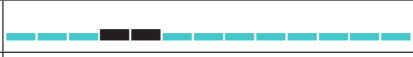 \\
\hline Geologija & 2007 & 4.6019 & 2010 & 2012 & 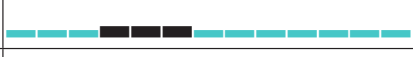 \\
\hline Construction and Building Materials & 2007 & 2.7728 & 2013 & 2015 & 2-1- \\
\hline Journal of Environmental Engineering-Asce & 2007 & 2.9719 & 2013 & 2015 & 2-1-1- \\
\hline Journal of Hazardous Materials & 2007 & 2.7259 & 2014 & 2016 & 2- \\
\hline Environmental Engineering and Management Journal & 2007 & 2.8845 & 2014 & 2016 & 2 \\
\hline Process Biochemistry & 2007 & 3.7446 & 2014 & 2016 & 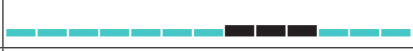 \\
\hline Chemical Engineering Journal & 2007 & 3.0421 & 2014 & 2019 & سمسعس \\
\hline Environment Impact Assessment & 2007 & 2.8013 & 2015 & 2019 & عسطسع \\
\hline Thesis & 2007 & 5.6552 & 2015 & 2019 & 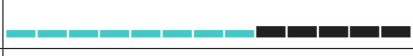 \\
\hline Environmental Earth Sciences & 2007 & 3.9306 & 2015 & 2019 & تسمس \\
\hline Journal of Environmental Management & 2007 & 3.6958 & 2015 & 2017 & - \\
\hline
\end{tabular}

Table 9. Top 7 references with the strongest citation bursts

\begin{tabular}{|c|c|c|c|c|c|}
\hline References & Year & Strength & Begin & End & $2007-2019$ \\
\hline $\begin{array}{l}\text { Investigation on the impact of transport exhaust } \\
\text { emissions on the air }\end{array}$ & 2004 & 3.3204 & 2007 & 2008 & 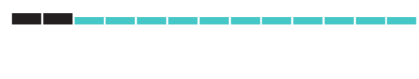 \\
\hline $\begin{array}{l}\text { Mathematical simulation of solid particle dispersion in } \\
\text { the air of Vilnius city }\end{array}$ & 2008 & 3.5428 & 2009 & 2011 & - \\
\hline Investigation of seaport air dustiness and dust spread & 2007 & 3.5964 & 2010 & 2011 & 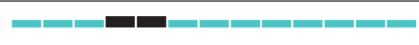 \\
\hline $\begin{array}{l}\text { Research on anaerobically treated organic waste } \\
\text { suitability for soil fertilisation }\end{array}$ & 2009 & 2.913 & 2011 & 2013 & 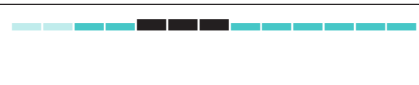 \\
\hline $\begin{array}{l}\text { Experimental investigation of biogas production using } \\
\text { fatty waste }\end{array}$ & 2008 & 2.913 & 2011 & 2013 & 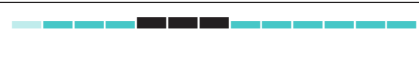 \\
\hline $\begin{array}{l}\text { Investigation into the air treatment efficiency of } \\
\text { biofilters of different structures }\end{array}$ & 2010 & 2.7818 & 2011 & 2014 & 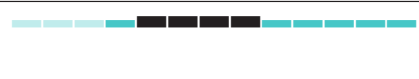 \\
\hline $\begin{array}{l}\text { Investigation of influence of lapse landfill leachate on } \\
\text { ground and surface water pollution with heavy metals }\end{array}$ & 2009 & 2.913 & 2011 & 2013 & 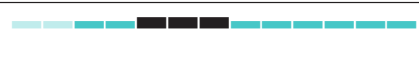 \\
\hline
\end{tabular}


filtration rate of the pollutant. Remarkably, the reference "Investigation of seaport air dustiness and dust spread" (Baltrènas, Fröhner, \& Pranskevičius, 2007) has the shortest duration, nevertheless, its strength is the strongest, which means that the reference is frequently cited from 2010 to 2011, and greatly assists the research for the two years. The paper investigates the causes of dust generation

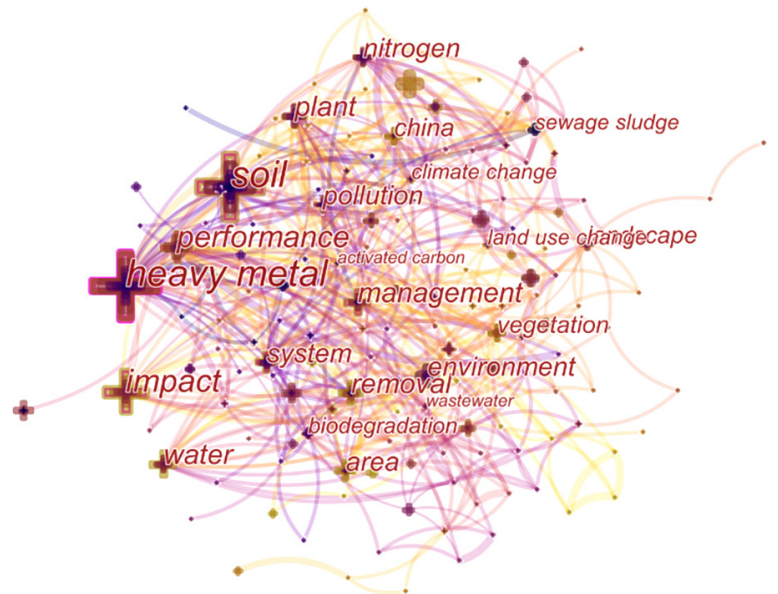

Figure 8. A visualization of the keyword network

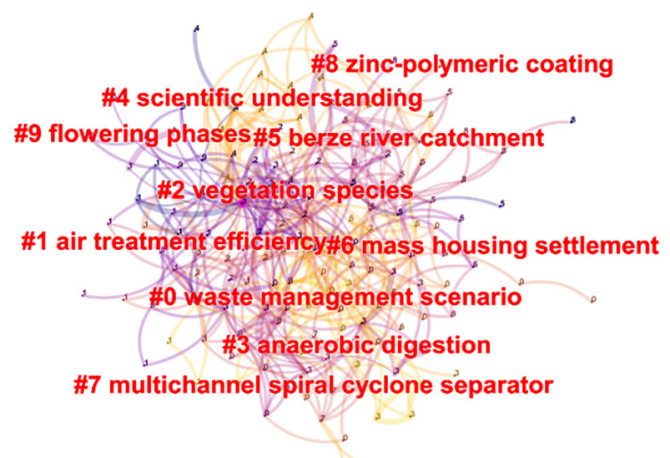

Figure 9. Cluster network of keyword research of JEELM and analyzed the main factors affecting dust concentration.

\section{Keyword network and timeline view analysis}

In order to directly clarify the current hot topics in the field of JE, the keyword analysis is essential. Figure 8 illustrates a visualization of the keyword network. We can easily find these keywords of most occurrences from it. The keywords of "heavy metal", "soil", "plant", "nitrogen", "water", and "impact", which occur frequently, belong to the field of engineering. Figure 9 lists the cluster network of keyword research of JEELM. It could help us know more about the hot topics. As can be seen from Figure 9, all the keywords are divided into 10 clusters. The biggest cluster is "waste management scenario"; hence waste management is a key and hot issue in the field of environment management. The second largest cluster is "air treatment efficiency", thus it can be seen that the issue of air is also vital to environmental management research. The third largest cluster is "vegetation species". It indicates that the research of vegetation species is a key to the development of the journal and the field. The timeline view of keywords shows the main keywords of JEELM's research at different time periods, leading us to know more about the trend of the hot topic in the corresponding field. Figure 10 is the timeline view of keywords for the JEELM publications since 2007. It could be found that the journal focuses more on the keywords of "heavy metal", "soil", "removal”, "nitrogen management", "plant", "performance”, "environment", "degradation" between 2007 and 2010. The keywords of "area”, "water", "impact", "water pollution", "remediation" occurred most between 2010 and 2013. From 2013 to 2016, the journal pays more attention to "vegetation", "sorption", "quality". The main keywords between 2016 and 2019 are "biochar", "restoration", "aqueous solution". We can see that keywords continually change

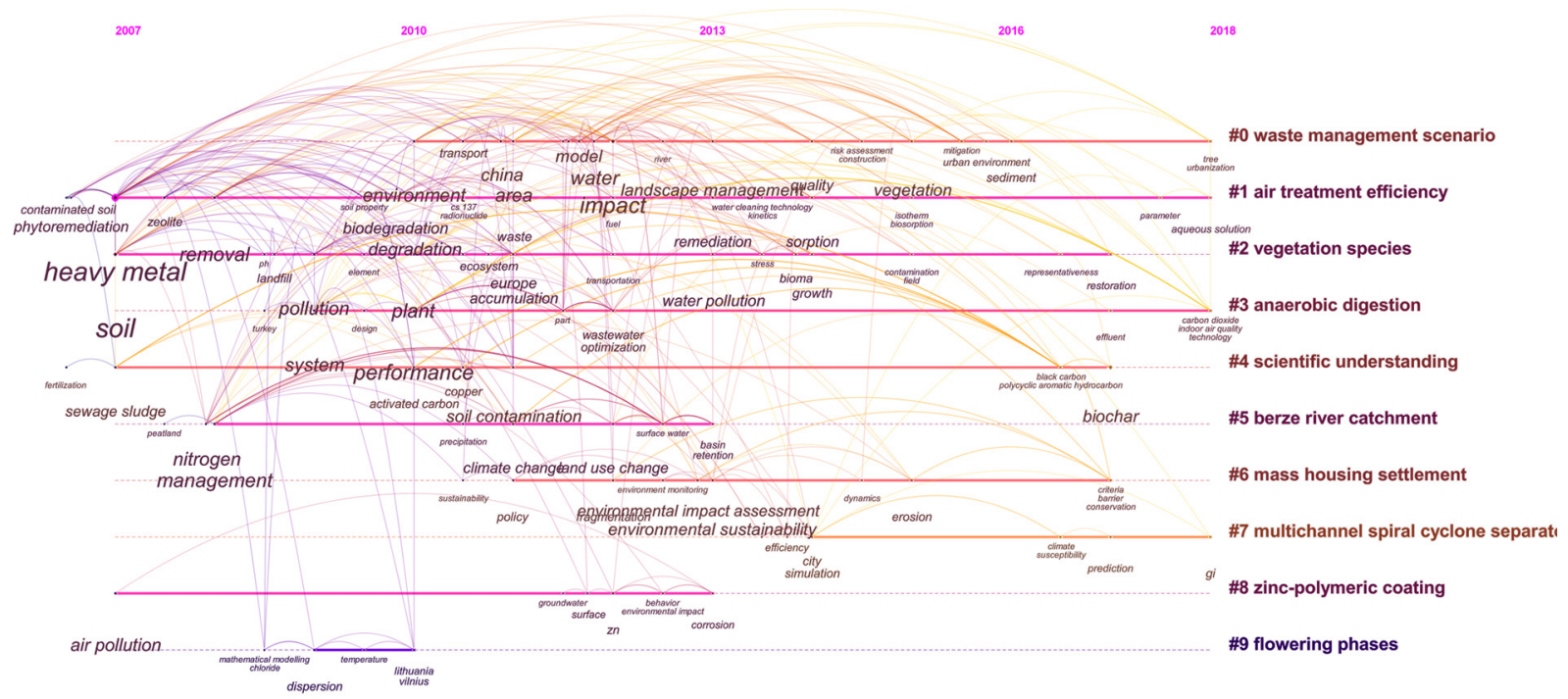

Figure 10. The timeline view of keywords for the JEELM publications 
over time, and people begin to care more about how to restore ecology instead of investigating and studying the detailed information of pollution sources before.

\section{Conclusions}

In this paper, we have made a comprehensive overview and clearly visualized analysis of JEELM. We have analyzed the current status and development trends of JEELM's research. There are 403 publications retrieved from WoS between 2007 and May 2019. Through analyzing the results given by CiteSpace, our findings are concluded as follows: The number of publications reached the peak in 2010. Besides, the article entitled "Sustainable construction taking into account the buildingimpact on the environment" (Medineckiene et al., 2010) is the most influential paper with 67 citations. Lithuania is the most influential country. As the publishing institution, there is no doubt that Vilnius Gediminas Technical University is the most influential institution. As the Editor-in-Chief, Baltrenas is the most influential author.

The citation bursts of the cited journals of Journal of Environmental Radioactivity and Chemical Engineering Journal have the longest citation burst duration with 6 years. The citation burst of the paper "Investigation into the air treatment efficiency of biofilters of different structures" has the longest citation burst duration with 4 years. As for the analysis of keywords, the keywords "heavy metal", "soil", "plant", "nitrogen", "water", and "impact" occur in JEELM frequently. In the cluster network of keyword research of JEELM, the biggest cluster is "waste management scenario". Moreover, from the timeline view of keywords, we have derived that people begin to care more about how to restore ecology instead of investigating and studying the detailed information of pollution sources before.

By providing the knowledge domain of JEELM, the current status and the future trends of development of the JEELM publications can be comprehensively learned which helps more researchers to know this journal and its research scope. Finally, we hope that more useful and comprehensive information, methods, factors, directions can be found in further investigations.

\section{Funding}

This work was supported by the $<$ Natural Science Foundation of China $>$ under Grant [numbers 71561026, 71571123 and 71840001] and <Applied Basic Research Programs of Science and Technology Commission of Yunnan Province> under Grant [number 2017FB102].

\section{Disclosure statement}

We have no financial, professional, or personal interests from other parties.

\section{References}

Alkan, H., Korkmaz, M., \& Tolunay, A. (2009). Assessment of primary factors causing positive or negative local perceptions on protected areas. Journal of Environmental Engineering and Landscape Management, 17(1), 20-27.

https://doi.org/10.3846/1648-6897.2009.17.20-27

Baltrènaitè, E., \& Butkus, D. (2007). Modelling of $\mathrm{Cu}, \mathrm{Ni}, \mathrm{Zn}$, $\mathrm{Mn}$ and $\mathrm{Pb}$ transport from soil to seedlings of coniferous and leafy trees. Journal of Environmental Engineering \& Landscape Management, 15(4), 200-207.

https://doi.org/10.1080/16486897.2007.9636931

Baltrènas, P., \& Zagorskis, A. (2010). Investigation into the air treatment efficiency of biofilters of different structures. Journal of Environmental Engineering and Landscape Management, 18(1), 23-31. https://doi.org/10.3846/jeelm.2010.03

Baltrènas, P., Fröhner, K. D., \& Pranskevičius, M. (2007). Investigation of seaport air dustiness and dust spread. Journal of Environmental Engineering \& Landscape Management, 15(1), 15-23. https://doi.org/10.1080/16486897.2007.9636903

Baltrènas, P., Vaitiekūnas, P., \& Mincevič, I. (2004). Investigation on the impact of transport exhaust emissions on the air. Journal of Environmental Engineering and Landscape Management, 12(1), 3-11.

https://doi.org/10.3846/16486897.2004.9636809

Baltrenas, P., Butkus, D., Nainys, V., Grubliauskas, R., \& Gudaitytè, J. (2007). Efficiency evaluation of a noise barrier. Journal of Environmental Engineering \& Landscape Management, 15(3), 125-134.

https://doi.org/10.3846/16486897.2007.9636920

Baltrènas, P., Vaitiekūnas, P., Vasarevičius, S., \& Jordaneh, S. (2008a). Modelling of motor transport exhaust gas influence on the atmosphere. Journal of Environmental Engineering and Landscape Management, 16(2), 65-75.

http://dx.doi.org/10.3846/1648-6897.2008.16.65-75

Baltrènas, P., Morkūnienè, J., \& Vaitiekūnas, P. (2008b). Mathematical simulation of solid particle dispersion in the air of Vilnius city. Journal of Environmental Engineering and Landscape Management, 16(1), 15-22.

https://doi.org/10.3846/1648-6897.2008.16.15-22

Baltrènas, P., \& Zagorskis, A. (2009). Investigation of cleaning efficiency of a biofilter with an aeration chamber. Journal of Environmental Engineering and Landscape Management, 17(1), 12-19.

https://doi.org/10.3846/1648-6897.2009.17.12-19

Chadyšienè, R., \& Girgždys, A. (2008). Ultraviolet radiation albedo of natural surfaces. Journal of Environmental Engineering and Landscape Management, 16(2), 83-88.

https://doi.org/10.3846/1648-6897.2008.16.83-88

Chen, C. M. (2006). CiteSpace II: Detecting and visualizing emerging trends and transient patterns in scientific literature. Journal of the American Society for Information Science and Technology, 57(3), 359-377. https://doi.org/10.1002/asi.20317

Chen, C. M. (2017). Science mapping: A systematic review of the literature. Journal of Data and Information Science, 2(2), 1-40. https://doi.org/10.1515/jdis-2017-0006

Chen, C. M., Hu, Z. G., Liu, S. B., \& Tseng, H. (2012). Emerging trends in regenerative medicine: A scientometric analysis in CiteSpace. Expert Opinion on Biological Therapy, 12(5), 593608. https://doi.org/10.1517/14712598.2012.674507

Claus, D., Dietze, H., Gerth, A., Grosser, W., \& Hebner, A. (2007). Application of agronomic practice improves phytoextraction 
on a multipolluted site. Journal of Environmental Engineering \& Landscape Management, 15(4), 208-212.

https://doi.org/10.1080/16486897.2007.9636932

Cui, T. N., \& Zhang, J. M. (2018). Bibliometric and review of the research on circular economy through the evolution of Chinese public policy. Scientometrics, 116(2), 1013-1037. https://doi.org/10.1007/s11192-018-2782-y

Ekanayake, E. M. A. C., Shen, G., \& Kumaraswamy, M. M. (2019). Mapping the knowledge domains of value management: A bibliometric approach. Engineering Construction and Architectural Management, 26(3), 499-514.

https://doi.org/10.1108/ECAM-06-2018-0252

Francisco, G. L., Mercedes, U. G., \& Bartolomé, M. L. (2016). The intellectual structure of research in hospitality management: A literature review using bibliometric methods of the journal International Journal of Hospitality Management. International Journal of Hospitality Management, 52, 121-130. https://doi.org/10.1016/j.ijhm.2015.10.007

Ghinea, C., Petraru, M., Bressers, H. T. A., \& Gavrilescu, M. (2012). Environmental evaluation of waste management scenarios-significance of the boundaries. Journal of Environmental Engineering and Landscape Management, 20(1), 76-85. https://doi.org/10.3846/16486897.2011.644665

Ginneken, L. V., Meers, E., Guisson, R., Ruttens, A., Elst, K., Tack, F. M. G., Vangronsveld, J., Diels, L., \& Dejonghe, W. (2007). Phytoremediation for heavy metal-contaminated soils combined with bioenergy production. Journal of Environmental Engineering and Landscape Management, 15(4), 227-236. https://doi.org/10.3846/16486897.2007.9636935

Grāvitis, J., Ābolinš, J., Tupčiauskas, R., \& Vēveris, A. (2010). Lignin from steam-exploded wood as binder in wood composites. Journal of Environmental Engineering \& Landscape Management, 18(2), 75-84.

https://doi.org/10.3846/jeelm.2010.09

Heersmink, R., Hoven, J. V. D., Eck, N. J. V., \& Berg, J. V. D. (2011). Bibliometric mapping of computer and information ethics. Ethics \& Information Technology, 13(3), 241-249. https://doi.org/10.1007/s10676-011-9273-7

Hirsch, J. E. (2005). An index to quantify an individual's scientific research output. Proceedings of the National Academy of Sciences, 102(46), 16569-16572.

https://doi.org/10.1073/pnas.0507655102

Kahraman, C., Ghorabaee, M. K., Zavadskas, E. K., Onar, S. C., Yazdani, M., \& Oztaysi, B. (2017). Intuitionistic fuzzy edas method: An application to solid waste disposal site selection. Journal of Environmental Engineering and Landscape Management, 25(1), 1-12.

https://doi.org/10.3846/16486897.2017.1281139

Kleinberg, J. (2002). Bursty and hierarchical structure in streams. Paper presented at Proceedings of the Eighth ACM SIGKDD International Conference on Knowledge Discovery and Data Mining-KDD '02, (pp. 91-101).

https://doi.org/10.1145/775047.775061

Kvasauskas, M., \& Baltrènas, P. (2009). Research on anaerobically treated organic waste suitability for soil fertilisation. Journal of Environmental Engineering \& Landscape Management, 17(4), 205-211.

https://doi.org/10.3846/1648-6897.2009.17.205-211

Lazdiņa, D., Lazdiņš, A., Kariņš, Z., \& Kāposts, V. (2007). Effect of sewage sludge fertilization in short-rotation willow plantations. Journal of Environmental Engineering and Landscape Management, 15(2), 105-111.

https://doi.org/10.3846/16486897.2007.9636916
Lu, Y., Li, Z., \& Arthur, D. (2014). Mapping publication status and exploring hotspots in a research field: chronic disease self-management. Journal of Advanced Nursing, 70(8), 18371844. https://doi.org/10.1111/jan.12344

Mažeikienè, A., Valentukevičienè, M., Rimeika, M., Matuzevičius, A. B., \& Dauknys, R. (2008). Removal of nitrates and ammonium ions from water using natural sorbent zeolite (clinoptilolite). Journal of Environmental Engineering and Landscape Management, 16(1), 38-44.

https://doi.org/10.3846/1648-6897.2008.16.38-44

Medineckienè, M., Turskis, Z., \& Zavadskas, E. K. (2010). Sustainable construction taking into account the building impact on the environment. Journal of Environmental Engineering and Landscape Management, 18(2), 118-127.

https://doi.org/10.3846/jeelm.2010.14

Morar, M., \& Agachi, P. S. (2010). Review: Important contributions in development and improvement of the heat integration techniques. Computers and Chemical Engineering, 34(8), 1171-1179.

https://doi.org/10.1016/j.compchemeng.2010.02.038

Niazi, M., \& Hussain, A. (2011). Agent-based computing from multi-agent systems to agent-based models: A visual survey. Scientometrics, 89(2), 479-499.

https://doi.org/10.1007/s11192-011-0468-9

Paulauskienè, T., Zabukas, V., \& Vaitiekūnas, P. (2009). Investigation of volatile organic compound (VOC) emission in oil terminal storage tank parks. Journal of Environmental Engineering and Landscape Management, 17(2), 81-88. https://doi.org/10.3846/1648-6897.2009.17.81-88

Pereira, P., \& Úbeda, X. (2010). Spatial distribution of heavy metals released from ashes after a wildfire. Journal of Environmental Engineering and Landscape Management, 18(1), 13-22. https://doi.org/10.3846/jeelm.2010.02

Pinto, A. L., Barquin, B. A. R., Gonzalez, J. A. M., \& Kauric, A. (2009). Analysis of the social network in serial publications: Representation in the Journal of Documentation. Investigation Bibliotecologica, 23(48), 13-32.

https://doi.org/10.22201/iibi.0187358xp.2009.48.16968

Pinto, M. (2015). Viewing and exploring the subject area of information literacy assessment in higher education (20002011). Scientometrics, 102(1), 227-245.

https://doi.org/10.1007/s11192-014-1440-2

Pundytè, N., Baltrènaitè, E., Pereira, P., \& Paliulis, D. (2011). Anthropogenic effects on heavy metals and macronutrients accumulation in soil and wood of Pinus sylvestris L. Journal of Environmental Engineering and Landscape Management, 19(1), 34-43.

https://doi.org/10.3846/16486897.2011.557473

Qaiser, F. H., Ahmed, K., Sykora, M., Choudhary, A., \& Simpson, M. (2017). Decision support systems for sustainable logistics: A review and bibliometric analysis. Industrial Management \& Data Systems, 117(7), 1376-1388.

https://doi.org/10.1108/IMDS-09-2016-0410

Reinhold, K., \& Tint, P. (2009). Hazard profile in manufacturing: Determination of risk levels towards enhancing the workplace safety. Journal of Environmental Engineering and Landscape Management, 17(2), 69-80. https://doi.org/10.3846/1648-6897.2009.17.69-80

Rusu, L. (2010). Application of numerical models to evaluate oil spills propagation in the coastal environment of the Black Sea. Journal of Environmental Engineering and Landscape Management, 18(4), 288-295.

https://doi.org/10.3846/jeelm.2010.33 
Sebo, P., Fournier, J. P., Ragot, C., Gorioux, P. H., Herrmann, F. R., \& Maisonneuve, H. (2019). Factors associated with publication speed in general medical journals: A retrospective study of bibliometric data. Scientometrics, 119(2), 1037-1058. https://doi.org/10.1007/s11192-019-03061-8

Simion, I. M., Fortuna, M. E., Bonoli, A., \& Gavrilescu, M. (2013). Comparing environmental impacts of natural inert and recycled construction and demolition waste processing using LCA. Journal of Environmental Engineering and Landscape Management, 21(4), 273-287.

https://doi.org/10.3846/16486897.2013.852558

Stopar, K., \& Bartol, T. (2019). Digital competences, computer skills and information literacy in secondary education: mapping and visualization of trends and concepts. Scientometrics, 118(2), 479-498. https://doi.org/10.1007/s11192-018-2990-5

Tang, M., Liao, H. C., \& Su, S. F. (2018). A bibliometric overview and visualization of the International Journal of Fuzzy Systems between 2007 and 2017. International Journal of Fuzzy Systems, 20(5), 1403-1422.

https://doi.org/10.1007/s40815-018-0484-5

Thijs, B., \& Glanzel, W. (2018). The contribution of the lexical component in hybrid clustering, the case of four decades of Scientometrics. Scientometrics, 115(1), 21-33. https://doi.org/10.1007/s11192-018-2659-0

Tian, X., Geng, Y., Zhong, S. Z., Wilson, J., Gao, C. X., Chen, W., Yu, Z. J., \& Hao, H. (2018). A bibliometric analysis on trends and characters of carbon emissions from transport sector, Transportation Research Part D: Transport and Environment, 59, 1-10. https://doi.org/10.1016/j.trd.2017.12.009

Touzani, M., \& Moussa, S. (2010). Ranking marketing journals using the search engine Google Scholar. Marketing Education Review, 20(3), 229-247. https://doi.org/10.2753/MER1052-8008200304

Turskis, Z., Lazauskas, M., \& Zavadskas, E. K. (2012). Fuzzy multiple criteria assessment of construction site alternatives for non-hazardous waste incineration plant in Vilnius city, applying ARAS-F and AHP methods. Journal of Environmental Engineering and Landscape Management, 20(2), 110-120. https://doi.org/10.3846/16486897.2011.645827

Užšilaityte, L., \& Martinaitis, V. (2010). Search for optimal solution of public building renovation in terms of life cycle. Journal of Environmental Engineering and Landscape Management, 18(2), 102-110. https://doi.org/10.3846/jeelm.2010.12

Vaitiekūnas, P., \& Banaitytè, R. (2007). Modeling of motor transport exhaust pollutant dispersion. Journal of Environmental Engineering and Landscape Management, 15(1), 39-46. https://doi.org/10.3846/16486897.2007.9636906

Vaitiekūnas, P., \& Jakštonienè, I. (2010). Analysis of numerical modelling of turbulence in a conical reverse-flow cyclone. Journal of Environmental Engineering and Landscape Management, 18(4), 321-328. https://doi.org/10.3846/jeelm.2010.37

Valenzuela, L., Merigo, J. M., Johnston, W. J., Nicolas, C., \& Jaramillo, J. F. (2017). Thirty years of the Journal of Business \& Industrial Marketing: A bibliometric analysis. Journal of Business \& Industrial Marketing, 32(2), 1-18.

https://doi.org/10.1108/JBIM-04-2016-0079
Van-Eck, N. J., \& Waltman, L. R. (2009). VOSviewer: A computer program for bibliometric mapping. Social Science Electronic Publishing, 84(2), 523-538.

https://doi.org/10.1007/s11192-009-0146-3

Van-Leeuwen, T. (2006). The application of bibliometric analyses in the evaluation of social science research: Who benefitsfrom it, and why it is still feasible. Scientometrics, 66(1), 133-154. https://doi.org/10.1007/s11192-006-0010-7

Wei, F. W., Grubesic, T. H., \& Bishop, B. W. (2015). Exploring the GIS knowledge domain using CiteSpace. Professional Geographer, 67(3), 374-384.

https://doi.org/10.1080/00330124.2014.983588

Xu, Z. S., Yu, D. J., \& Wang, X. Z. (2019). A bibliometric overview of International Journal of Machine Learning and Cybernetics. between 2010 and 2017. International Journal of Machine Learning and Cybernetics, 10(9), 2375-2387. https://doi.org/10.1007/s13042-018-0875-9

Yu, D. J. (2015). A scientometrics review on aggregation operator research. Scientometrics, 105(1), 115-133. https://doi.org/10.1007/s11192-015-1695-2

Yu, D., Xu, Z., \& Šaparauskas, J. (2019). The evolution of “Technological and Economic Development of Economy": a bibliometric analysis. Technological and Economic Development of Economy, 25(3), 369-385. https://doi.org/10.3846/tede.2019.10193

Yu, D., Xu, Z., Pedrycz, W., \& Wang, W. (2017). Information Sciences 1968-2016: A retrospective analysis with text mining and bibliometric. Information Sciences, 418, 619-634. https://doi.org/10.1016/j.ins.2017.08.031

Zavadskas, E. K., Kaklauskas, A., Turskis, Z., \& Kalibatas, D. (2009). An approach to multi-attribute assessment of indoor environment before and after refurbishment of dwellings. Journal of Environmental Engineering and Landscape Management, 17(1), 5-11.

https://doi.org/10.3846/1648-6897.2009.17.5-11

Zhang, X. L., \& Li, H. (2018). Urban resilience and urban sustainability: What we know and what do not know? Cities, $72,141-148$.

https://doi.org/10.1016/j.cities.2017.08.009

Zhao, F. K., Shi, B., Liu, R. X., Zhou, W. K., Shi, D., \& Zhang, J. S. (2018). Theme trends and knowledge structure on choroidal neovascularization: A quantitative and co-word analysis. BMC Ophthalmology, 18(1), 86. https://doi.org/10.1186/s12886-018-0752-Z

Zhong, B. T., Wu, H. T., Li, H., Sepasgozar, S., Luo, H. B., \& He, L. (2019). A scientometric analysis and critical review of construction related ontology research. Automation in Construction, 101, 17-31. https://doi.org/10.1016/j.autcon.2018.12.013

Zigmontienè, A., \& Zuokaitè, E. (2010). Investigation into emissions of gaseous pollutants during sewage sludge composting with wood waste. Journal of Environmental Engineering and Landscape Management, 18(2), 128-136. https://doi.org/10.3846/jeelm.2010.15 